EESTI NSV TEADUSTE AKADEEMIA TOIMETISED. KEEMIA

ИЗВЕСТИЯ АКАДЕМИИ НАУК ЭСТОНСКОИ ССР. ХИМИЯ

PROCEEDINGS OF THE ACADEMY OF SCIENCES OF THE ESTONIAN SSR. CHEMISTRY $1984,33,2$

К. ЛЭЭТС, Т. КААЛ, Малле ШМИДТ, А. КУУЗИК, А. КОГЕРМАН, Лууле МЕТСПАЛУ, Кюлли ХНИЕСААР

\title{
СИНТЕЗ АНАЛОГОВ ЮВЕНИЛЬНОГО ГОРМОНА
}

\author{
5. ПОЛУЧЕНИЕ И ЮВЕНИЛЬНАЯ АКТИВНОСТЬ \\ НЕКОТОРЫХ АЛКОКСИАЛКЕНИЛФЕНИЛОВЫХ ЭФИРОВ
}

K. LAATS, T. KAAL, MALLE SCHMIDT, A.KUUSIK, A, KOGERMAN, LUULE METSPALU, KOLLI HIIESAAR. JUVENIILHORMOONI ANALOOGIDE SUNTEES.. 5. MONEDE ALKOKSIALKENOULFENOULEETRITE SAAMINE JA NENDE JUVENIILNE AKTIIVSUS

K. LAATS, T. KAAL, MALLE SCHMIDT, A. KUUSIK, A. KOGERMAN, LUULE METSPALU, KOLLI HIIESAAR. SYNTHESIS OF JUVENILE HORMONE ANALOGUES 5. PREPARATION OF SOME ALKOXYALKENYL PHENYL ETHERS AND THEIR JUVENILE ACTIVITY

K настоящему времени синтезировано большое число аналогов ювенильного гормона насекомых (АЮГ) [1]. Наиболее активные из них применяются как инсектициды, безопасные для биосферы. В 1976 г. в качестве АЮГ предложены алкоксиалкил- и алкоксиалкенилфениловые эфиры [2]. Они получаются из замещенных фенолов и соответствующих галогенидов. Однако выход последних довольно низок, а путь синтеза исходя из метилвинилкетона трудоемок - он проходит в четыре этапа [ $\left.{ }^{3}\right]$.

3-Метил-5-алкокси-2-пентениловые эфиры замещенных фенолов

\begin{tabular}{|c|c|c|c|c|c|c|c|c|c|}
\hline \multirow{2}{*}{ Исходный фенол } & \multirow{2}{*}{ 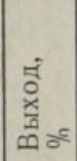 } & \multirow{2}{*}{$\begin{array}{l}\text { T. кип., } \\
{ }^{\circ} \mathrm{C} / \text { мм }\end{array}$} & \multirow{2}{*}{$d_{4}^{20}$} & \multirow{2}{*}{$n_{D}^{20}$} & \multicolumn{2}{|c|}{ Найдено, } & \multicolumn{2}{|c|}{$\begin{array}{c}\text { Вычислено, } \\
\%\end{array}$} & \\
\hline & & & & & $\mathrm{C}$ & $\mathrm{H}$ & C & $\mathrm{H}$ & 冢 \\
\hline
\end{tabular}

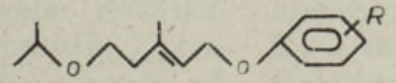

$n$-Крезол

м-Крезол

3,4-Диметилфенол

$n$-Метоксифенол

$n$-Хлорфенол

\begin{tabular}{l|l}
63 & 1 \\
49 & 1 \\
60 & 1 \\
36 & 1 \\
40 & 150
\end{tabular}

\begin{tabular}{|c|c|c|}
3,9738 & 1,5008 & 77,64 \\
0,9741 & 1,5040 & 77,50 \\
0,9712 & 1,5064 & 78,05 \\
1,0095 & 1,5048 & 73,01 \\
1,0675 & 1,5010 & 67,30
\end{tabular}

\begin{tabular}{r|r}
10,02 & 77,36 \\
10,05 & 77,36 \\
10,15 & 77,80 \\
9,15 & 72,68 \\
8,11 & 67,05
\end{tabular}

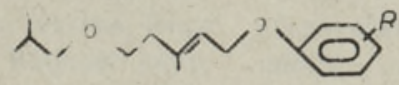

n-Крезол м-Крезол 3,4-Диметилфенол $n$-Метоксифенол

\begin{tabular}{l|}
61 \\
54 \\
62 \\
37
\end{tabular}

$\begin{aligned} & 78,10 \\ & 77,45 \\ & 78,57 \\ & 73,55\end{aligned} \mid$

\begin{tabular}{r|r}
10,13 & 77,80 \\
10,20 & 77,80 \\
10,40 & 78,23 \\
9,70 & 73,35
\end{tabular}

\begin{tabular}{r|c}
9,99 & 5 \\
9,99 & 30 \\
10,21 & 0,5 \\
9,42 & 30
\end{tabular}


Нами для получения алкоксиалкенилхлоридов применена реакция теломеризации изопрена с $\alpha$-хлорэфирами [ $\left.{ }^{4}\right]$. Из продуктов реакции 1-хлор-3-метил-5-алкокси-2-пентенов (R-i-Pr и $i$-Bu) и замещенных фенолов при действии $\mathrm{NaOH}$ в диметилсульфоксиде [5] - получены 3-метил-5-алкокси-2-пентениловые эфиры замещенных фенолов (см. таблицу). Все полученные соединения, по данным ГЖХ, представляют собой смеси геометрических изомеров, причем $E$ - и $Z$-изомеры образуются в соотношении $\sim 3: 1$.

По данным Института зоологии и ботаники АН ЭССР, большинство из синтезированных алкоксиалкенилфениловых эфиров обладает средней ювенильной активностью на мучном хрущаке (Tenebrio molitor L.).

Теломеризацию изопрена с $\alpha$-хлорэфирами проводили по методике, описанной нами в [6]. Получено два продукта. 1-Хлор-3-метил5-изопропокси-2-пентен: т. кип. $69-75^{\circ} \mathrm{C}(5 \mathrm{mм}), d_{4}^{20} 0,9491$ и $n_{D}^{20} \quad 1,4544$. Содержание Cl 19,8\% (вычислено 20,1). Выход 70\%. 1-Хлор-3-метил5 -изобутокси-2-пентен: т. кип. $72-80^{\circ}$ (2 мм), $d_{4}^{20} 0,9414$ и $n_{D}^{20} 1,4531$. Содержание Cl 18,1\% (вычислено 18,6). Выход $67 \%$.

Фениловые эфиры получали по методике, описанной в [5].

\section{ЛИТ Р РА Т У Р А}

1. Sláma, K., Romaňuk, M., Sorm, F. Insect Hormones and Bioanalogues. Wien-New York. 1974.

2. Jarolim, $V$., Sehnal, $F$., Sláma, $K$., Sorm, $F$. Insekticidni prostředek na podkladě juvenilniho hormonu hmyzu a zpusob jeho připravy. - Авт. свнд. ЧССР № $163097,1976$.

3. Jarolim, V., Sorm, F. Synthesis of some 9-oxa and 10-oxa analogues of acyclic juvenoids. - Collect. Czech. Chem. Commun., 1975, 40, N 4, 1059-1069.

4. Пудовик А. Н., Алтунина $H$. Присоединение $\alpha$-галоидоэфиров к изопрену. Ж. общ. хим., 1956, 26, вып. 6, 1635-1639.

5. Шехтер О. В., Цизин Ю. С. Синтез 7-метил-6-октенилфениловых эфнров. Ж. орган, хим., 1977, 13, вып. 5, 993-995.

6. Лээтс K., Каал T., Шмидт М., Кудрявцева К. Влияние природы катализатора на теломеризацию, изопрена с $\alpha$-хлорметилизопропиловым эфиром. - Изв. АН ЭССР. Хим., 1980,29 , № 3, 232-234.

Институт химии

Академии наук Эстонской ССР

Институт зоологии и ботаники

Академии наук Эстонской ССР
Поступила в редакцию 22/IX 1983 